\title{
The Family and the Elderly in Spanish Society: The Exercise of Testamentary Freedom When the Testator Reaches the Age of Eighty
}

\author{
Paloma de Barrón Arniches \\ Department of Private Law, Faculty of Law, University of Lleida, Lleida, Spain \\ Email: pbarron@dpriv.udl.cat
}

How to cite this paper: de Barrón Arniches, P. (2019). The Family and the Elderly in Spanish Society: The Exercise of Testamentary Freedom When the Testator Reaches the Age of Eighty. Beijing Law Review, 10, 1020-1050.

https://doi.org/10.4236/blr.2019.104055

Received: July 13, 2019

Accepted: September 22, 2019

Published: September 25, 2019

Copyright ( 2019 by author(s) and Scientific Research Publishing Inc. This work is licensed under the Creative Commons Attribution International License (CC BY 4.0).

http://creativecommons.org/licenses/by/4.0/

\begin{abstract}
The rules that in the civil legal systems regulate the succession upon death, highlight the conception that every legal text has about individual freedom, and also about the family. The variety of Spanish civil laws includes very different systems on the compulsory portion. And this shows up (because of that), that variety of conceptions. This paper analyzes the disinheritance as an exercise of the testamentary freedom to deprive the compulsory portion to certain relatives. The research aim is to show the differences and the common points between Spanish civil laws and to propose some legal reforms. The research method used consists on the analysis of the most relevant statistics about the Spanish population and on the most frequent decisions of the elderly regarding their descendant's inheritance. Also, last year main judicial decisions and the authors' opinions have been analyzed.
\end{abstract}

\section{Keywords}

Elderly, Family Relations, Testamentary Freedom, Disinheritance

\section{Introduction}

Time and again, when writing about inheritance law and testamentary freedom, we must refer to the current social reality, to the historical moment in which we are assessing the efficiency of the various laws in force on the matter. We must contemplate the diverse solutions proposed by each of the seven civil law rules that coexist in Spain for a social reality that has evolved in parallel in all the country's regions since the second half of the last century.

Indeed, life expectancy has increased by more than thirty years in Spain since 1940. Coupled with the declining birth rate, this means that, on average, there 
are 2 million people over the age of 80 in the country, more than half of whom, from that age on, have difficulty carrying out their daily activities and need the material and emotional support of younger people (http://www.who.int/ageing/about/facts/en/). Of the almost 3 million people living alone in Spain, 450,000 are over the age of 80 . Specifically, 140,000 people between the ages of 85 and 89 live alone, a figure that climbs to 250,000 in the case of people aged 80 to 84

(http://www.ine.es/jaxi/tabla.do?type=pcaxis\&path=/t00/mujeres hombres/tabla $\underline{\text { s } 1 / 10 / \& \text { file }=\text { d01001.px). }}$.

In contrast, according to data from the Bank of Spain, the highest net wealth in households is produced when the head of the family is between 55 and 64 years old. In other words, hereditary succession usually occurs at the time of the greatest wealth for the inheritor

(http://www.bde.es/f/webbde/SES/Secciones/Publicaciones/PublicacionesSeriada s/DocumentosOcasionales/08/Fic/do0810.pdf) and thus does not constitute his or her main economic lifeline; rather, status and livelihood are mainly the result of cultural capital (education).

These data suggest that, in keeping with the literature, today the law of succession is less important than in the past (Delgado, 2012), and that the right to the compulsory share, provided for under all the succession systems in force today in Spain-except the Ayala and Navarre systems, which provide for a purely nominal compulsory share-does not fulfill the same economic and social purpose as in the past. Consequently, its social interest should be revisited (Parra, 2009).

The concept of family has likewise changed considerably in recent decades. Family refers to the smallest area of daily life, the so-called nuclear family. Family relationships have become increasingly vertical as more and more families have fewer children and parents and grandparents live longer (López, González, \& Sánchez, 2015). Family changes are also directly related to the significant increase in divorce (source: INE, Statistics on Annulments, Separations and Divorces for 2015) for example, due to the resulting concurrence of children from different marriages or the presence in the inheritance of a widow or widower who is not the parent of the deceased's descendants. The upward trend in the number of reconstituted families is clear; in 2011, such families acounted for 7.5\% of all families, twice as many as in 2001 (Rivas, 2012, Navas, 2013). In this context, there is a constant concern for the legal protection of the surviving spouse-or, today, partner in a stable relationship-to the detriment of the children (Bosch, 2017). Parents usually encourage their children to complete professional training, providing financial support while they do so, or guarantee them a livelihood through various mechanisms of wealth transfer. Once they have done that, when the future decedent is a person in the final stretch of his or her life, the rules regarding the compulsory share are often regarded as a real impediment to his or her testamentary freedom (Orozco, 2016). The need or desire that people express to "discriminate" among their descendants, favoring the 
one deemed neediest, is also a relevant issue arising, in particular, in cases in which one family member has a disability (Garrido, 2009, Jou, 2015).

All these realities must be considered when analyzing the institution of disinheritance that, albeit with different formulations, exists in Spain's civil systems and allows the testator to deprive all or some of his or her entitled relatives of their compulsory share (Rebolledo, 2010b: p. 30, Rams, Moreno, \& Rubio, 2017; Román, 2016, Blasco, 2013). This paper aims to consider the role of the institution of disinheritance from the perspective of people exercising their testamentary freedom in the final stretch of their lives.

In light of the above considerations, first, it is necessary to assess the position of the elderly when they undertake the task of planning their succession. They benefit from a number of advantages over the young when exercising this right, in particular, the possibility of knowing the circumstances of each family member, which is most likely an established situation. It is thus easier for them to make the right decisions by treating their successors unequally according to their actual needs. Older people also have fairly accurate knowledge of the possibilities and needs of their life partner-whether a spouse or other form of partner-and similarly know what they do not want to happen as a result of their death, often due to past experiences (e.g., family disputes or the application of inheritance rules that favor the children at the widow or widower's expense, Gomá 2017).

However, there are also risks, especially the risk of waiting too much to make succession decisions, such that by the time an elderly person does so, he or she is less capacitated, due to age or illness. The elderly may also be dangerously influenced by relatives or third parties or even have lost the equanimity and good judgment associated with good physical and mental health. As the elderly population grows, so does the risk of diseases that can affect people's volitional capacity. There are many more cases of testators who are more vulnerable due to age or physical and mental health issues, which can easily lead to cases of undue influence on their disposition mortis causa (Spanish authors: García 2014; Vaquer, 2015, Lasarte, 2007. For a non-Spanish perspective on this doctrine: Spivack, 2010, Madoff, 1997; Scalise, 2008; Kerridge, 2000, y 2002, Ridge, 2004, Hartog, 2012).

In short, in the final period of life, the average testator has two main objectives: to secure the future of their spouse once they are gone (It is a major argument in the literature that a significant number of married people would like to favor their spouse in their dispositions mortis causa beyond what is allowed by the rules protecting the compulsory share of their descendants, Delgado, 2012) or, if the testator is single or already widowed, to reward or protect those who care for them in their final days, whether or not they are relatives (Garrido, 2009; Jou, 2015). To this end, in their 2008 reform, Catalan lawmakers established the proviso that if a person wishes to favor their professional caregiver mortis causa, they must make a will or succession agreement before a notary, i.e., the intervention of a notary public to assess the testator's capacity and free will is mandatory (Art. 412-5.2 Catalan Civil Code (CCCat), Del Pozo, Vaquer, and Bosch, 2017; 
Gómez, 2009, Sonnekus, 2007). This legislative option is in keeping with an international trend arising precisely as a result of people's increasing longevity (the German Heim Gesetz or Section 21350 of the California Probate Code attach the sanction of absolute nullity to any provision in favor of the professional caregiver or residential center). However, it offers a more balanced solution than that advocated by the legal doctrine of undue influence, as it enables the notary to exercise a cautionary action to assess whether or not the possibility of undue influence has been taken into account, so that the testator can dispose in favor of their caregiver provided that that is their freely formed will.

In this social context one must ask about the efficiency of disinheritance. As currently regulated, does it work to get rid of unwanted persons entitled to a legitime, so to speak? In other words, if we ignore the cases in which disinheritance is used as an instrument to sanction criminal conduct by forced heirs, in which the institution usually works, with the courts upholding the testator's will to punish, when what marks the life of the testator beyond the threshhold of the age of 80 is filial lack of affection and neglect, or a lack of support in illness or solitude, is disinheritance an efficient tool for making family relationships more supportive?

Finally, when the testator honestly thinks that one of his or her forced heirs does not need the money, whereas other people or institutions do, is disinheritance really an instrument to make the legitimary institution more flexible so that the testator's will regarding the post-mortem fate of his or her estate can be fulfilled?

\section{The Basis of the Compulsory Share in Current Spanish Systems, or How to Make the Compulsory Share Compatible with the Current Social and Family Reality}

To begin to answer these questions, I will now briefly address the foundation of the different variants of the compulsory share system in force in Spain. Some authors note that the compulsory share could be constitutionally protected if it is considered a form of protection of the family and, thus, a suitable means to reconcile the freedom to dispose implicit in Article 33 of the Spanish Constitution (CE) and the protection of the family provided for under Article 39CE (Rogel, 2017; Busto, 2015; Zubero, 2017).

In contrast, most authors hold that the constitutional protection affects testamentary freedom, not the institution of the legitimary. The matter of testamentary freedom must be considered first, as a manifestation of human dignity and the free development of personality applied to the law of succession (Delgado, 2012). Testation is a form of self-realization (Torres \& García, 2014). The right to private property and inheritance are protected by Article 33 CE (López, 1997), which recognizes the right of an individual to dispose of their property, not only in life but also after their death; the Constitution thus guarantees inheritance as a consequence of the recognition of private property. The status of owner includes the ability to dispose of property intervivos, and also the ability to dispose of it 
after death itself (Art. 17 of the Charter of Fundamental Rights of the European Union (July 31, 2008, 184 BOE).

However, in the various inheritance systems, the freedom of the testatoris not cited as an absolute power and is furthermore disparately specified, as are the different legal systems. Testamentary freedom is considered an eminently personal power that makes it possible to bestow benefits on other people, basically by deciding the content of the inheritance instrument employed (what property to leave to whom). The guarantee of inheritance under the Spanish Constitution is a corollary of the recognition of private property, not an instrument of protection of the family. Nevertheless, the legitimacy of ordinary lawmakers to impose limits on testamentary freedom in order to enhance the social function of property is clear.

Although this social function does not include the essential content of the right to private property, it certainly does shape the ways in which the testator can exercise his or her powers as the owner. The fact that the compulsory share constitutes a legal limit on material freedom does not automatically make it an institution of public order in Spain (Some authors have addressed this issue, making special reference to German law, based on the famous sentence of the Constitutional Court of April 19, 2005, Vaquer, 2007; Delgado, 2012, Sánchez 2016). Nevertheless, the legitimary system is quite important for the purposes of organizing one's own succession, that is, of exercising individual testamentary freedom. Lawmakers intervene to determine which shares of the inheritance or portions of the estate should be allocated to which of the decedent's kin and the legal nature of this law. They decide whether it is an individual or collective compulsory share, the amount, and whether it should be allocated to certain of the decedent's kin over others. We must ask ourselves about the basis for the legitimary system, examining its effectiveness in the current historical moment with regard to the circumstances described in the previous section, i.e., the planning of one's own succession by the elderly. As Vaquer has said "si a lo único que atiende la legítima es al interés familiar, de modo que su fundamento es la condición de pariente con derecho a legítima, y, más en concreto, si la legítima representa un deber del causante para con sus legitimarios, la consecuencia que debe extraerse es que procede interpretar las normas aplicables en beneficio de loslegitimarios. En los sistemas legitimarios sin desheredación o con causales muy estrictas, el legislador otorga primacía al legitimario. Sólo las ofensas más graves, las constitutivas de indignidad sucesoria, o acompañadas de alguna específica de gravedad remarcada, permiten la privación de la legítima" (Vaquer 2007).

This lucid reasoning points to the underlying motives of many judicial decisions settling disputes related to the compulsory share, namely, that in the legal systems in force in Spain, the compulsory share is set up as a law for the person entitled to a legitime; the future decedent has a legal duty toward that person, but the opposite is not true (Throughout this paper, I will refer to various recent judgments certifying this judicial reality. They are mainly judgments of the Pro- 
vincial Courts following the Supreme Court's decisions of June 3, 2014, and January 30,2015, which are supposed to be beginning to apply the new, relevant Supreme Court doctrine concerning the interpretation of some causes of disinheritance). This is despite the fact that part of the literature situates the foundation for the compulsory share in intergenerational solidarity (Parra, 2009; Ferrer, 2011; Cañizares, 2014, Torres \& García, 2014, Arroyo \& Farnós, 2015).

This is because, first, any obligations the person entitled to a legitime might have toward the testator are not legal obligations, but rather pertain to the sphere of conscience. In other words, the obligations of solidarity between the people entitled to a legitime and the testator are not reciprocal, at least legally. In addition, technically the exercise of solidarity requires a prior situation of need. From the perspective of the future decedent's obligations toward his or her family members, this would refer solely to inheritance law concerning alimony. This provision is only found in Spain in the collective share systems. In contrast, in the rest of the civil systems, the legitime is based on reasons of kinship or the relationships arising from marriage or partnership, and the amount is based on legislative policy, not any kind of solidarity between family members. As already noted, the compulsory share is generally conveyed to the next generation at a point when the legitimaries already have sufficient financial means for their sustenance (mentioned data from the Bank of Spain show that, in general, the right to the legitime arises at the time of greatest wealth of the legitimary). Furthermore, it is allocated equally, irrespective of the different economic needs of each of the people entitled to a legitime.

In my opinion, it is necessary to rethink the concept of intergenerational solidarity as it is applied in civil-law systems. This would allow us to coherently analyze how the institution of disinheritance works. In the following pages, I will consider its inefficiency as a mechanism for truly encouraging two-way solidarity between family members, i.e., by the testator toward the person entitled to a legitime and by that person toward the testator. By way of example, in cases of disinheritance with just cause, this is what occurs in relation to the legal limits concerning the cause for the disinheritance and the procedure to be followed first by the testator and then by the heir should the person entitled to a legitime file a judicial claim. Were it to result in the dooming of the disinherited legitimary to a situation of economic necessity, in individual compulsory share systems such a circumstance would not trigger any type of solidarity mechanism that would result in the use of the decedent's estate to address that situation of need.

Spanish legal systems have certainly evolved toward a progressive weakening of the compulsory share (Art. 243 Law 2/2006, of June 14, Civil Law of Galicia, LDCG, Art 486, Legislative Decree 1/2011, of March 22, of the Government of Aragon, CFA, Art. 243 LDCG, Art. 238 LDCG, Art. 486 CFA, Art. 451-4 CCCat), but have they managed to truly modify the foundation for it or its raison d'être? Why have these reforms not affected the institution of disinheritance, except in the case of Catalonia? 
If the compulsory share continues to be based on the legitimary's sacred right on the grounds of his or her family ties to the decedent, how can the rule be interpreted and applied coherently in cases of disinheritance? Has a solution really been achieved for the case of a testator who does not want, for founded reasons, to be bound by the legal require met to attribute some of his or her estate to some of the relatives entitled to a legitime?

\section{How Disinheritance Works in Spanish Civil Law}

This section adresses, on one side, the Spanish civil laws of collective compulsory share (section 3.1., about The Basque country and Aragón) and, on the other side, the Spanish civil laws of individual compulsory share (section 3.2, about the laws of the rest of Spanish territory). This way, the different legal problems and issues which are formulated in each civil system are shown. In addition, I state what my opinion is on each matter to which I allude to.

The origins of disinheritance can be traced back to classical Roman Law; the testator had to institute certain relatives (the sui) as heirs or disinherit them. Disinheritance was intended to maintain discipline within the family by strengthening the testator's authority. At first, no reason was required, i.e., in practice, the freedom to disinherit, and, therefore, the freedom of testation, was absolute. This remained the case until the causes allowing disinheritance were introduced under Emperor Justinian, non-observance of which could give rise to the total or partial invalidity of the testament by means of the "querela inoficiosi testamenti."

Today, disinheritance continues to exist in systems of Roman origin, with the notable exception of the Italian Codice Civile (CCI) and the French Code, which do not provide for the institution of disinheritance. Instead, these systems have opted for a "pure system"-in some ways more coherent-whereby a compulsory share based on parental bonds cannot be suppressed regardless of the behavior of the so-called "forced heir," unless the latter meets one of the grounds for being declared unworthy to inherit (Arts. 726 and 727 French Code. As for Italy, see Art. 463CCI concerning the cases of "unworthiness" that may also affect forced heirs).

In France, the legitimary system underwent a major reform in 2006. The reform turned the French legitime into a credit claim and abolished the right to the compulsory share for ascendants, although it did not introduce the institution of disinheritance (Malaurie \& Brenner, 2016).

In Italy, the notion of the right to a compulsory share safeguards the legitimary from any intention by the testator to deprive him or her of his or her legal share (Perlingieri, 1951, Cantelmo, 1972; Mengoni, 2000; Tatarano, 2008; Campagnolo, 2011; Albanese, 2012; Galgano, 2012; Fusaro, 2011; Moscati, 2013) However, the literature has seen a significant shift and increasingly emphasizes the need to respect the will of the testator. Thus, some experts in civil law have begun to reinterpret Italian inheritance law from the perspective of the current 
social reality, under the protection of constitutional principles and European private law (Barba 2013; Bonomi, 2011; Perlingieri, 2005; Bonilini, 2009; Bartoli, 2018).

These experts explore formulas for reassessing and enhancing the exercise of private autonomy in the context of legal business mortiscausa, albeit without depriving the legitimaries of their right to take actions to protect themselves by defending their compulsory share, where appropriate. As for the principle of solidarity, the most recent literature suggests that it should not be considered in isolation, but rather be judged in each specific case, balancing the interests at stake and according to the criterion of reasonableness (Barba, 2013).

In the compulsory share systems in force in Spain, disinheritance is regulated as a formal act whereby the testator deprives the legitimary of his or her status as such and the possibility of requesting what would have been his or her compulsory share, provided the legitimary has committed any of the legal causes justifying disinheritance. Whether or not the disinheritance is stipulated in a testament or any other succession instrument depends entirely on the testator. First, the testator may exercise his or her freedom not to disinherit the legitimary even if there are legally valid causes to do so. The testator may also exercise this freedom by pardoning the legitimary for hisor her behavior or reconciling with him or her. In contrast, should the testator decide to disinherit one or more legitimaries, he or she will have to show that the situation he or she is experiencing and the behavior attributed to the legitimary "fit" within the narrow margin of the legally classified causes for disinheritance.

\subsection{The Difficulty of Combining Disinheritance with Separation in Collective Compulsory Share Systems}

Disinheritance coexists with separation or exclusion in the systems that provide for a collective compulsory share, i.e., the systems in force in the Basque Country and Aragon. The testator has a legal obligation to his or her closest relatives, but also the power to choose which among them will actually receive the material compulsory share. The descendants are legitimized first, but the testator may choose among them, even if they are less closely related (Art. 51.1 LDCV: "EI causante podrá disponer de la legítima a favor de sus nietos o descendientes posteriores, aunque vivan los padres o ascendientes de aquellos.", See also, Art. 486 CFA) (Sánchez-Rubio, 2012).

\subsubsection{The Basque Country}

The law governing successions in the Basque Country (the Basque Civil Law Act, hereinafer, LDCV), which was reformed in 2015, is one of the modern laws that link the foundation for the compulsory share with the principle of solidarity and the social function of property:

"La concepción vasca de la propiedad es modulada por la función social de la propiedad y por el principio de solidaridad. Junto a la propiedad individual, las leyes ampararán las diversas formas de propiedad comunal, familiar y social 
peculiares del Derecho civil vasco de forma que las mismas se acomoden a la realidad social del tiempo en que deban ser aplicadas." (Statement of reasons LDCV).

Although the new law has considerably undermined the institution of the compulsory share, it is clear that the foundation for its existence continues to be the goal of favoring future generations, "protecting family property" through this attributed inheritance imposed by law.

Prior to the reform, the Basque Country had a plural and fragmented inheritance system. The compulsory share as provided for under the Spanish Civil Code (CCE) was in force in much of the territory, while separate systems were in force in Tierra Llana de Bizkaia and the Fuero de Ayala, in addition to another set of regulations governing the inheritance of farmsteads in Guipúzcoa. Thus, part of the Basque territory had a system of individual compulsory shares, while another part had a system of collective ones. The influence of Castilian law translated not only to the application of the CCE in part of the territory, but also to the fact that the valid collective compulsory share in Vizcaya covered four fifths of the flow to the widow or widower, as under the Siete Partidas, or Seven Parts, the medieval Code compiled under King Alfonso X the Learned.

The new law unifies the system governing this legal attribution, establishing a collective compulsory share for the whole territory. This share now applies only to descendants, like the one previously in force only in Bizkaia, but the amount has been reduced to one third of the hereditary estate, with the regime of absolute testamentary freedom being maintained in Valle de Ayala (Álava) (Galicia 2016, Gil, 2016). The new Basque law deprives ascendants of the right to a compulsory share. The spouse or stable partner has the status of legitimary, but their right is specified as a right of usufruct of varying amounts depending on whether or not they coincided with the decedent's children.

Beyond that, the collective compulsory share allows the testator to choose, that is, to decide which descendant will receive the material compulsory share consisting of one third of the estate. This mechanism, known as "separation," does not affect the spouse's usufruct in any way (Fernández, 2015) Separation supposes that there are several people entitled to a legitimein a descending straight line or, where applicable, several relatives at the same level in this line, and it does not have to be justified, causal, or conditional; it is valid simply because it is the testator's freely stated will (STSJPV, 15.05.2007, RJ 2008\618.) The law in force since 2015 in the Basque Country seems to seek to expand the testator's testamentary freedom, as it expressly provides that the omission of separation is the same as a tacit separation and that preterition, intentional or otherwise, of a descendant is equivalent to his or her separation. Therefore, the separation, whether express or tacit, omission of separation, and preterition, intentional or otherwise, of a legitimary descend an tall have the same effect (Galicia 2016).

The only real limit to the Basque testator's freedom in relation to his or her descendants is that he or she cannot leave everyone, or, where applicable, the 
sole legitimary, out of the inheritance. The compulsory share is based on kinship and that portion of the inheritance must be for a legitimary, i.e., a forced heir. Thus, if a testator does not want his or her only child or, if there are more, any of his or her children to receive the compulsory share, he cannot use separation to achieve that goal; if he or she fails to allocate anything to any of them in the succession, it would be a case of disinheritance, whether just or unjust, or intentional preterition.

Under Article 51.2 LDCV, total preterition (of all the people entitled to a legitime) nullifies the inheritance provisions related to the estate. In other words, when the testator leaves all or his or her sole legitimary out of the inheritance, the testament becomes void, which, in turn, can result in the opening of an intestate succession (Urrutia, 2016). Surprisingly, as a result of this legislative decision, should the testator decide that none of the legitimaries deserves to receive the compulsory one-third share, the entire inheritance is offered $a b$ intestato. It is a solution that only makes sense if the legitimary's preterition is erroneous, (Galicia, 2016) and, of course, it is a very different solution from that provided for in the other Spanish legitimary systems. Under those systems, in cases of intentional preterition, the will remains intact, but the people entitled to a legitimecan claim their right. It is also different from the solution applied in the Basque Country for the disinheritance without just cause-supposedly similar to intentional preterition-of all or the sole legitimary. In that case, the provisions of the CCE apply, as the suppletive law (Art. 3 LDCV).

In effect, as disinheritance is not regulated in the new Basque civil law, its regulation must be inferred from the CCE, which the LDCV stipulates is the suppletive law. The law does not regulate the legal causes for disinheritance, or how the institution works. However, the wording of Article 50 LDCV, concerning the right of representation, does presuppose the existence of disinheritance in the Basque Country. Thus, in a case of disinheritance without cause, Article 851 CCE applies, i.e., the decedent's dispositions mortiscausa are not annulled but rather reduced as needed to cover the one-third compulsory share of the disinherited heir (STS, 15.02.2001, RJ 2001\1484).

Lawmakers have missed a valuable opportunity to clarify how disinheritance works in this collective compulsory share system, which is quite different from the individual compulsory share provided for under the CCE. Unjust disinheritance should logically be equated with separation and intentional preterition: the lack of a material individual compulsory share in the Basque civil order prevents Article 851 from being applied verbatim and without nuances, although that is consistent with its status as suppletive law. Therefore, if any of the various existing legitimaries is unjustly disinherited or separated, the effects are the same: he or she loses all material rights to receive any specific property within the collective compulsory share but retains his or her rights against third parties, as well as the right to inherit from the decedent should an intestate succession ultimately be opened (Art. 59.2 LDCV, Judgment of the Provincial Court of Vizcaya of June 15, 2015, JUR 2015\207037, and Judgment of the Provincial 
Court of Vizcaya, of April 19, 2013, JUR 2014\148499). If the legitimary is the decedent's sole descendant, he or she cannot be separated or disinherited without cause, since he or she will retain the right to receive the portion of the estate constituting the compulsory one-third share designated by law for at least one of the decedent's descendants.

Thus, just disinheritance (i.e., one in which one of the causes provided for under the CCE, as the suppletive law in the Basque Country, exists) is the only means by which the right to a compulsory share, both formal and material, could be extinguished absolutely for all the people entitled to a legitime. Therefore, in this case, Basque testators are comparable to the people subject to the individual material compulsory share system provided for under the CCE, insofar as they will encounter the same difficulties to effectively achieve the goal of depriving their descendants of their compulsory share.

An example of this reality can be found in the case settled in the judgment of the Provincial Court of Guipúzcoa of December 19, 2016. The plaintiffs were four children entitled to a compulsory share who had brought an action to (partially) challenge the will executed by D. Hezekiah. The fourth clause of the will disinherited the children "for having denied the testator support for no legitimate cause" and thus deprived them of any right to their inheritance, adding that the aforementioned cause for the disinheritance was strictly true and included in Article 853.1 CCE. The defendant heirs requested the dismissal of the lawsuit alleging that the testator's children had no relationship with their father, that they had not offered any emotional, economic, or face-to-face support, despite knowing he had cancer, and that they also refused to partition the inheritance from their mother, who had died earlier, and liquidate the shared property. The trial judge assessed the evidence and found that there was emotional neglect of the father by the children, and that one could even speak of psychological abuse, given the parent's anxiety and grief over the behavior of his children, who, since 2000, had not even called him, despite knowing that he was mortally ill. Based on those arguments, he dismissed the claim. However, the Provincial Court had no choice but to overturn the sentence on the grounds of incongruity, because the contested testament did not include disinheritance for the cause stipulated in Article 853.2 CCE, but rather exclusively for the cause stipulated in the first paragraph of that article, which is the refusal, without legitimate cause, to provide support. The Court recalled the case law of the Supreme Court, which has long noted that "ha de imponerse una interpretación restrictiva en materia de desheredación que no sólo proclama el art. 848 del Código Civil, sino también la abundante jurisprudencia orientada en la defensa de la sucesión legitimaria; no admitiéndose ni la analogía, ni la interpretación extensiva, ni siquiera la argumentación de "minoris ad maiorem", indicating, in relation to the provision of support that, "la falta de relación afectiva y comunicación entre la hija y el padre, el abandono sentimental sufrido por éste durante su última enfermedad, la ausencia de interés demostrado por su hija, en relación con los problemas del padre etc., son circunstancias y hechos que de ser ciertos, corresponden al cam- 
po de la moral, que escapan a la apreciación y a la valoración jurídica, y que en definitiva sólo están sometidos al Tribunal de la conciencia."In keeping with this same restrictive interpretation, in relation to the cause for disinheritance consisting of denying support to a parent or ascendant for no legitimate reason (Article 853.1), in its judgments of November 4, 1997 (RJ 1997, 7930), and March 26, 1993, the Supreme Court recalled the sanctioning nature of the rule and the resulting need to interpret the causes for disinheritance strictly, denying that the lack of relationship between the heirs and the decedent, the decision to deprive him of their presence in life in order to comfort him during his final illness, and other similar behaviors could be subsumed within the unjustified refusal to provide support.

\subsubsection{Aragon}

In Aragon, the compulsory share, which corresponds only to the descendants and has always been collective, encompasses half of the inheritance (Art. 486 CFA). The reduction of the amount of the collective compulsory share, from two thirds to half of the hereditary estate, was implemented by Law 1/1999, of February 24, on succession on account of death. The collective nature of the Aragonese compulsory share actually refers to the testator's freedom to distribute it among the group of descendants; it does not give rise to any collective or group right (Parra \& Barrio, 2012). The group of legitimaries lacks personality and cannot be the holder of any right. Unlike the Basque law, Articles $503 \mathrm{ff}$. of the Code of Aragonese Regional Law (hereinafter, CFA) do expressly regulate preterition, disinheritance, and exclusion, in that order. The systematic disposition of the precepts in the Aragonese law concerning these institutions enables their joint operation, since, as Vallet de Goytisolo has said, in practice, separation significantly resembles disinheritance, except that it does not require a cause for the separation from the inheritance (Vallet, 1974).

There are two types of exclusion of the legitimary in Aragon: the voluntary exclusion of descendants, after which the excluded forced heir retains his or her rights vis-à-vis third parties should there be a quantitative infringement of the collective right; and absolute exclusion, which entails the loss of all rights not only in the testate succession but also in the legal succession $a b$ intestato, as well as the possibility of bringing an action for injury of the collective right. However, if the absolute exclusion affects all the people entitled to a legitime or the sole legitimary, then they are considered subject to simple or voluntary exclusion (Art. 513.3 CFA, Judgment of the Court of Justice of Aragon, of September 22, 2011, RJ: 2012 13073) In other words, just as in the Basque civil system, the compulsory share cannot be extinguished absolutely and for all legitimaries merely by the will of the testator, because the compulsory share is based on kinship. Hence, to extinguish absolutely the right to a compulsory share, both formal and material, the disinheritance must be performed with just cause. The rules governing how this institution works are similar and adhere to the same principles as those contained in the CCE, i.e., the cause for the disinheritance 
must be true and expressed in the succession agreement or testament, and, especially, should any disinherited legitimary deny that there is just cause, the burden of proof to show it lies with the decedent's heirs (Sanchez-Rubio 2016) An example of this can be found in the judgment of the Provincial Court of Zaragoza of November 9, 2010, in which the Court declares the right of the testator's grandchildren to half of the hereditary estate as a compulsory share because they had been disinherited without legal cause (the grandmother had stated in her will that she had disinherited them because "no le saludaban pese a vivir en la misma casa y no le han prestado atención de ningún tipo, no poniendo en su conocimiento el fallecimiento de su padre, hijo de la testadora" (JUR 2011\42105; See also Barrón, 2017, Sánchez-Rubio, 2016).

In short, in both the Basque Country and Aragon, the institution of disinheritance is unnecessary if what the testator wants is to choose among his or her descendants, because there is already separation or exclusion for that. (One example is the Judgment of the Provincial Court of Teruel, of December 14, 2016, ROJ: SAP TE 159/2016: “Así las cosas, el testador no ha desheredado a su hija Violeta, ni ha vulnerado la legítima, sino que tan solo ha hecho uso de la fiducia que tenía encomendada y atribuido a uno solo de los herederos el remanente hereditario"). In contrast, if the testator is over the age of 80 and has no relationship with and does not feel cared for by his or her children, or if he or she simply considers that these children no longer need his or her assets and thus wishes to disinherit them all, he or she will face the same challenges and limitations as imposed under the legitimary system provided for in the CCE. That system, it should be recalled, defends the right of the children due to kinship at all costs and, for that very reason, does not effectively foster solidarity within families. The contrast between the broad distributive freedom enjoyed by testators who have more than one descendant and the narrow path to disinheritance with legal cause available to them should they wish to disinherit all or their sole child or descendant is striking. It is as if the two institutions, which are opposed in terms of both their foundations and how they work, do not entirely fit within the same legitimary system.

\subsection{The Limited Viability of Disinheritance When It Is Not Based on the Commission of Serious Punishable Criminal Offenses by the Legitimary}

In light of the aforementioned cases, which show that even in Aragon and the Basque Country disinheritance must be undertaken on the basis of just cause, it is clear that the practical problems that disinheritance poses affect all the legitimary systems in Spain equally. I will try to sort out these issues, some of which have already been mentioned above. I will limit the analysis to cases in which the freedom of testation is intended to be exercised through the disinheritance of legitimary descendants, not because they have committed punishable criminal offenses, but because either there has been a situation of material neglect or emotional detachment by the people entitled to a legitime in relation to 
the testator or the testator understands that those people do not need their legitimary share and wishes to leave it to other people or institutions instead.

First, it should be recalled that in the latter case disinheritance does not work. It would be considered unjust, and the people entitled to a legitime would retain their right to the compulsory share.

As for the rest of the cases, i.e., behaviors constituting material or emotional neglect, I have already referred to the substantive issue hindering the viability of attempts to deprive legitimaries of their compulsory share, namely, that the true basis of the right to the compulsory share is none other than kinship. It thus logically follows that the courts interpret the rules from the standpoint of the legitimary and the defense of his or her rights as kin to the decedent (See the Judgment of the Provincial Court of Cordoba of October 16, 2017 (JUR|2017\300272), when it dismisses a case of disinheritance because it does not consider that there has been psychological abuse of the deceased: "Debemos tener presente que los derechos legitimarios (cuya desheredación se pretende) aparecen ligados en nuestro ordenamiento jurídico a los lazos de parentesco y no de afectividad."). In addition, there are two main challenges affecting the practical viability of the institution of disinheritance: the rigidity of the legal standard and the procedural attribution of the burden of proof to the heir in the litigation of claims to a legitime brought by disinherited legitimaries.

\subsubsection{The Rigidity of the Legal Standard}

It is not easy for courts to interpret rigid rules flexibly on their own; on the contrary, the wording of the rules governing disinheritance in Spanish legitimary systems urges judges to practice a formalistic interpretation, aimed at preventing the institution's viability in cases in which each and every one of the requirements are not met, or are not met as expressed in the law (Torres \& Dominguez, 2016). The reason for this rigidity is precisely because disinheritance is conceived of as a private sanction (Jordano, 2004; Rebolledo, 2010a, Algaba, 2002; Albaladejo, 2013; Barrón, 2016), therefore, the "sanctioned" acts must be truly deserving of such consequence. However, nowadays, neglect and lack of solidarity with the elderly are still not considered punishable, at least not unanimously or broadly. Not even since the start of the new trend in case law, initiated with the Supreme Court's judgments of June 3, 2014, and January 30, 2015, can family solidarity and children's duties toward their parents be said to have gained any ground in the hermeneutic approach used by the provincial courts that might result in the flexibilization of the institution of disinheritance (By way of example, see the Judgment of the Provincial Court of Cuenca of December 30, 2016 (AC\2016\2165).

In contrast, when the collective legitimary system regulates the possibility of excluding one or more people entitled to a legitime, the testator's power to do so is not linked at all to any specific reprehensible behavior on the part of the separated legitimary. The exclusion does not imply any civil sanction: it is not necessarily exercised on the basis of a moral judgment that the testator performs re- 
garding the observed behavior of those of his or her kin entitled to a legitime. Therefore, should the testator decide to separate one or more of these people, he or she is not condemning them for misbehavior, but rather freely deciding to distribute the compulsory share unequally, whether because he or she considers that the people entitled to a legitime have unequal needs or for any other reason. The distributive freedom is granted to the testator as a skillful tool for achieving a post mortem distribution of the estate in accordance with his or her interests and those of his or her family environment, not to separate someone who is estranged or to sanction such a person for previous behavior. Hence, the excluded individual is entitled to file a claim against third parties should the testator dispose of his or her estate beyond the legal limits to the detriment of the overall legitimary share (art. 512.2 CFA).

With regard to the disinheritance for just cause of all Basque or Aragonese legitimaries, or of any person entitled to a legitime in all other Spanish territories, we must recall the formalities that the rule requires the testator to meet. First, the disinheritance must be recorded in a will or, where applicable, another succession instrument. Disinheritance may not be performed by means of an act between living people, nor may other indirect means of depriving the legitimaries of their right be used. Art. 423-10.2 CCCat provides that "la exclusión de un sucesor que tiene la condición de legitimario deja subsistente su derecho a reclamar la legitima." Therefore, it would not be effective to try to deprive an heir of his compulsory share by appealing to all of the heirs who will determine the rules to govern the intestate inheritance except for the legitimary who one wants to leave out. Also illustrative is the Judgment of the High Court of Justice of Galicia, of October 18, 2005, RJ\2005\7545, concerning a donation and life contract, which concludes that disinheritance without cause cannot be covered under a different simulated business that does not meet the legal requirements of Art. 849 CCE: "Existe simulación relativa (art. 6.4 del Código Civil) porque bajo los negocios aparentes-vitalicio y donación-no queridos se oculta otro realmente querido-el de desheredación-de modo que aquellos no se sustentan en la causa verdadera que objetivamente cumplen (art. 1.276 del Código Civil) sino que se encaminan a un resultado o función distintos y como sucede que este fin-desheredación fuera de testamento y sin expresión de causa legal de acuerdo con el art. 849 del Código Civil-es contrario al ordenamiento jurídico." Disinheritance may not be partial or conditioned. According to the provisions of Art. 451-18 CCCat, disinheritance may only be imposed absolutely, just as the behavior of the legitimary may only be forgiven absolutely. Likewise, should the legitimary challenge the disinheritance, the courts may only lift or maintain the sanction, depending on the evidence presented in the proceedings.

The disinheritance clause must designate the disinherited legitimary individually and unequivocally and state the legal cause attributed to him or her. Only the CCC at expressly regulates the requirement for the nominal designation of the disinherited legitimary. However, this requirement can be extrapolated to all 
compulsory share systems, because it is deduced from the very nature of the institution, as the courts have pointed out (Judgment of the Provincial Court of Salamanca, of May 27, 2015, JUR 2015\147629). In my opinion, total disinheritance intensifies, once again, the formal and restrictive nature that the institution is intended to have, forcing it to be performed through taxed and narrow channels, without leaving room for the testator to freely resolve the family conflict in which he is immersed. The Roman origin of the prohibition on partial disinheritances could be cited, and its relationship with the legitimary's status as a "forced heir." However, that view lacks a foundation in current civil law, in which the compulsory share can be attributed by any title, even if they all stem from Roman sources (Vallet, 1974; Jou, 1994; Bosch, 2002; Álvarez, 2014). It is not necessary, however, according to the case law, for the testator to cite the cause of disinheritance with the exact wording of the law itself (STS, 25.09.2003, RJ 2003\6442, which quotes, among others, STS, 15.06.1990, RJ 1990\4760). This affords the testator a small margin to explain in his or her will the reasons why he or she has decided to disinherit someone. It may even provide evidence in advance that will later help the heir prove the facts attributed to the people entitled to a legitime. Because, in fact, as I will discuss below, should a disinherited legitimary deny the existence of the legal cause and claim his or her compulsory share, the burden of proving the existence of just cause in the disinheritance performed by the decedent will correspond to the heir (Art. $850 \mathrm{CCE}$, also applicable in Galicia, Balearic Islands, and the Basque Country, Art. 451-20 CCCat, and Art. 509.2 CFA. Note that the proposed reform of the Civil Code advocated by the Association of Civil Law Professors likewise does not modify this aspect: "La prueba de ser cierta la causa de la desheredación corresponde a los herederos del causante si el desheredado la niega.").

\subsubsection{Attribution of the Burden of Proof and the Real Possibilities the Testator Gives His or Her Heirs of Defending the Disinheritance}

In my opinion, the fact that it is the heir who bears the burden of proof in case of litigation is a decisive factor in the decision to challenge the practical effectiveness of disinheritance in court. In fact, I think it is the main reason why so many disinherited people claim their compulsory share. At the same time, I think it is one of the factors discouraging the use of disinheritance by those who, having reached the age of 80 , must plan their succession. First, the future decedent knows that it will most likely lead to litigation after his or her death. He or she also knows that he or she will not be there when the challenge reaches the courts and, therefore, will not be able to help his or her successor or successors argue their case and prove that the disinherited legitimaries committed the actions he or she considers so reprehensible.

Even beyond these arguments, the task of preparing evidence in advance that this system imposes on the elderly is obviously too burdensome. It is not at all pleasant to describe, even before the notary notarizing the will, family secrets involving neglectful or detached behaviors by people who should have shown solidarity in the face of a situation of weakness or need on the part of their eld- 
ers. And even if the testator wishes to do so, he or she may not always be in the necessary physical or mental condition to assume that burden. As a result, in most of the many cases brought to dispute a disinheritance, the heir is forced to accredit past situations, which he may not be fully familiar with and which, for the most part, took place in the private sphere of the family, i.e., without witnesses who might be considered minimally impartial. (The Judgment of the Provincial Court of Valencia, of April 19, 2016, AC\2017\483; the Judgment of the Provincial Court of Cuenca, of December 30, 2016, AC\2016\2165; the Judgment of the Provincial Court of Asturias, of June 13, 2016, JUR\2016\173005; the Judgment of the Provincial Court of Cordoba, October 16, 2017, JUR 2017\300272; and the Judgment of the Provincial Court of Girona, December 28, 2017, AC\2017\1758, among others).

With regard to the lack of effective ability to record before a notary the reality of a family situation of abuse or disaffection, or even to detect attempted manipulation by the closest relatives, we must once again recall the susceptibility associated with old age. This susceptibility affects the elderly person's testamentary freedom, understood as the set of circumstances needed for the free determination of the will that the testator must meet at the time the succession instrument is drawn up (Del Pozo, Vaquer, \& Bosch, 2017). This basic principle is protected by the legal system through the cause of unworthiness to inherit, included in Article 756.5 CCE, and in very similar terms in the rest of the Spanish succession systems (Art. 412.3 g) CCCat, Art. 328, f CFA for example) Under this cause, anyone who uses threat, fraud, or violence to compel the testator to grant, modify, or revoke a disposition mortis causa is considered unworthy to inherit. Catalan lawmakers have further stipulated that anyone who knows of these facts and takes advantage of them is likewise unworthy to inherit (Gómez, 2009). The manipulation or tortious deceit of the elderly to make them violate their will mortis causa is clearly a form of psychological abuse against which the legal system must act.

The courts have had occasion to define the actions of intimidation and manipulation of the elderly that affect testamentary freedom. The Judgment of the High Court of Justice of Catalonia of April 8, 2010 (STSJ Catalonia, 8.04.2010, RJ 2010 3617 ), is certainly illustrative. In that case, the person named as the beneficiary in the penultimate testament of the deceased sued the beneficiary of the final testament and managed to prove the existence of manipulation of the deceased at the time the latter was drafted and, therefore, that it suffers from vices of consent, in accordance with the provisions of Art. 422 CCCat. In addition, the plaintiff requested that the defendant be declared unworthy to inherit: “(...) podemos decir que hay fuerza moral cuando se inspira a una persona el temor racional y fundado de sufrir un mal inminente y grave sino accede a las pretensiones de otra, de tal forma que produce una inhibición de su voluntad y el pronunciamiento o exteriorización de otra distinta, debiendo ahondarse para calificar la intimidación como de grave o no grave, a la edad y a la condición de la persona pues la capacidad de influir en la toma de decisiones no depende solo 
de los concretos y objetivos actos realizados sino de la posibilidad de influir con ellos en la formación de la voluntad. En este sentido no será igual ni pueden valorarse del mismo modo presiones ejercidas en personas jóvenes o saludables, con posibilidad de desenvolverse por sí mismas, que las dirigidas a personas mayores $y$ desvalidas." Thus, the presuppositions of this cause of unworthiness, which are simultaneously causes for declaring the nullity of the will due to vices of consent, would be as follows: a) that the unworthy person's behavior was intended to manipulate or control the testator's will, thereby vitiating it, and that this induction was done illegally, i.e., the conduct need not be a criminal offense, but it must be qualified as unlawful; and b) that the granting, revocation, or modification of the testament, or, where applicable, the lack of such actions, against the true will of the deceased is a direct or immediate consequence of this tortious behavior by the unworthy person. Therefore, there must be a causal relationship between the offender's behavior and the effect of impeding the genuine expression of the will mortis causa of the manipulated testator (Judgment of the Provincial Court of Barcelona, of July 27, 2009, JUR 2009\417006). Needless to say, in such cases, the person so influenced or manipulated will almost never be in condition or have the moral strength needed to apply the institution of disinheritance against the legitimary, because of either the psychological abuse or the attempt to control their will.

In short, the different inheritance systems that regulate the causes for disinheritance include the causes for unworthiness to inherit (Art. 852 CCE, Art. 451-17.2.a CCCat, Art. 263 LDCG, Art. 510 CFA, Art. 46 CDCIB; Jordano, 2004.; Algaba, 2011) Lawmakers thus intend for testators themselves to defend the integrity of their testamentary will (García \& Otero, 2016). However, very few people use this cause for disinheritance, because they either lack the moral strength to face their intimidator or they are being emotionally manipulated by him or her and may not even be aware of the deception to which they are being subjected (Another recent example can be found in the Judgment of the Provincial Court of the Balearic Islands of December 20, 2016 (AC/2016/2147), which declares the existence of manipulation by a son of his father to achieve a succession agreement defined to his benefit and to the detriment of his brother). In contrast, the most frequent outcome in the courts is for the testament or succession agreement drawn up by the deceased to be declared null due to the existence of manipulation, and for the beneficiary of the nullified succession instrument to then be declared unworthy to inherit for the same cause (See also the collected case law in the Judgment of the Provincial Court of Barcelona, of February 19, 2015, JUR 2015 (227987).

In summary, practice shows that the testator cannot always prepare evidence in advance of the grounds for the legitimary's disinheritance, as he or she may not even be able to do so. Thus, in situations of abuse based on the vulnerability of the elderly, the mechanism of unworthiness is much more efficient than that of disinheritance. Any legitimary deemed incapable of succeeding the deceased on the grounds of unworthiness to inherit will already be deprived of his legi- 
time without the need for a cause of just disinheritance. And in those cases in which the testator is able to prepare evidence in advance, it can hardly be carried out under the necessary conditions for disinheritance based on a lack of family solidarity to prosper: as noted, it is not a pleasant task to perform nor does it seem appropriate in the current social context to place the burden for that responsibility on the elderly.

\subsubsection{The Scope of the New Trend in the Case Law and of the Reform of the Catalan System in Cases of Psychological Abuse and Lack of Family Relationship with the Decedent}

Some relevant recent judgments of the Supreme Court do seem to have changed the rules of the game. I am referring to the new interpretation of Article 853.2 CCE in cases of psychological abuse of the testator by people entitled to a legitime (SSTS 3.06.2014, JUR181499 and 30.01.2015, RJ 2015\639). This doctrine should be understood to be extendable to the legitimary systems in which disinheritance is governed by the rules of the CCE, because it is the suppletive law in the absence of specific regulations in this regard (i.e., the systems in force in the Basque Country, Galicia, and the Balearic Islands). The Judgment of the Provincial Court of Coruña, of December 4, 2014 (ROJ: SAP C 3208/2014), and the Judgment of the Provincial Court of Santiago de Compostela, of November 7, 2014, JUR 2015\79445, are examples of this.

The 2008 reform of the Catalan legitimary system, which introduced as a new cause of disinheritance a lack of family relationship attributable to the legitimary (Article 451.17 e) of the Catalan Civil Code (hereinafter, CCCat)), and its application by the courts go in the same direction. However, are these judicial or even legislative solutions proving effective? To what extent has there been an increase in intra-family solidarity, even under the threat of losing the legitimary share?

Indeed, it is often said that the broader the possibility of justifying a disinheritance is, the greater the scope of the testamentary freedom and vice versa, i.e., the more restrictive the interpretation of the causes for disinheritance, the narrower the scope of that freedom (Vaquer, 2017). Catalan lawmakers introduced the cause of manifest and continued absence of a family relationship in an attempt to link the maintenance of the compulsory share with its evolution in keeping with today's society. The courts have also echoed the current moment of change in relation to the inheritance process, introducing a new hermeneutic approach to the causes of disinheritance (De Almansa, 2012), at least with regard to the "open causes," i.e., those whose legal expression allows some margin for interpretation and in which the testamentary freedom of the testator takes on a greater role.

Beginning with the Supreme Court's recent cases law, which can be considered extendable to all the systems in force in Spain (SSTS 3.06.2014, and 30.01.2015) it is clear that the concept of mistreatment is evolving. Both cases deal with a situation of "emotional neglect," of abuse by the descendant, and of the absence of personal and economic support for the testator. In both cases, the 
testator decided to disinherit the descendant who had left the testator in such a state, and in both cases the Court concluded that the disinheritance was based on just cause.

The literature immediately addressed the importance of the Supreme Court's new approach in a proliferation of commentaries and analyses of the aforementioned sentences (Salas, 2014; González, 2015; Algaba, 2015; Barrón, 2016; Carrau, 2015, Clemente, 2017). Not only the literature, but also society as a whole applauded the new approach proposed by the Supreme Court as opposed to the obsolete system provided for under the CCE. (See some of the newspaper articles published around the time of the sentences, including: "Desheredar, mision imposible," (August 31, 2014) El País; "Desheredación y libertad de testar," (September 2, 2014) El Mundo; and "Quiero desheredar a mi hijo," (April 18, 2015) El País.

Thus, the Supreme Court's judgment of January 30, 2015, provides: "Se denuncia la infracción del art. 853.2 del Código Civil, y de la jurisprudencia de esta Sala (...), en relación con la interpretación y significado que en conjunto confieren a la expresión haberle maltratado de obra como causa de desheredación de un padre respecto a alguno de sus hijos. Considera la recurrente que el maltrato psicológico que las sentencias de ambas instancias ha considerado probado es de tal entidad que debe entenderse incluido en el concepto de maltrato de obra reseñado en el Código Civil, ya que de conformidad con la jurisprudencia de esta Sala no es necesario el empleo de violencia física para configurar la situación de maltrato de obra que da pie a entender aplicable la aludida causa de desheredación. Ha quedado probado que la causante sufrió un trato desconsiderado de su hijo, quien le despojó sin ninguna consideración de todos sus bienes inmuebles a través de una fraudulenta donación que, engañada, le obligó a hacerle a él y a sus hijos, ante notario, con inevitable afección en el plano psicológico o psíquico, intolerable a la luz de la realidad social en la que resulta altamente reprobable el hostigamiento económico habido del hijo para con su madre." An analysis of the Provincial Court judgment to which this cassation appeal refers (Judgment of the Provincial Court of Castellón, of July 24, 2013, JUR 2013\324441) is extremely revealing. It was proven that the mother only wanted to donate one property to her son, but that he conspired to have other properties included in the deed. These circumstances are quite reminiscent of the situation of manipulation of the elderly to which I referred in the previous section, as a cause of both unworthiness to inherit and for disinheritance. However, in this case, the testator marshalled the strength needed to turn against the manipulative and interested son and decided, first, to bring an action to revoke the donation and, second, to draw up a will disinheriting the son (albeit alleging the causes provided for under Article 853.2, rather than Article 756.5, CCE). The Court did not consider that the circumstances constituted mistreatment; however, through a somewhat dubious interpretive technique, the Supreme Court decided to consider the alleged cause to be valid and the disinhe- 
ritance just.

For its part, the Supreme Court judgment of June 3, 2014, which initiated the trend toward the more flexible interpretation in the case law of Article 853.2 CCE, contemplated an even more "psychological," or "non-abusive," situation, since there was no economic dispossession of any kind of the testator. Instead, the Supreme Court found that: “(...) quedó probado que los hijos abandonaron al padre durante los últimos siete años de vida, donde, ya enfermo, quedó al amparo de su hermana." The judgment places more emphasis on the father's loneliness in his last seven years of life than on the insults uttered by the two children prior to that or on the physical aggression he had suffered at the hands of one of them when they lived together. What had taken place was not physical or psychological mistreatment, but rather emotional neglect, originating, as shown in the proceedings, in the testator's legal separation from his wife, who was the mother of the people entitled to the legitime and whose side they had taken during the separation. The Provincial Court concluded that the children consciously engaged in psychological abuse of their father. The Supreme Court confirmed this thesis and, acknowleding that psychological abuse can also be considered mistreatment, seemed to suggest that a system limited to recognizing generic "mistreatment" as a cause for disinheritance would be preferable, leaving it to the judge to decide, in each case, whether or not there had been a serious breach of family duties.

However, most of the literature holds that the psychological abuse provided for under the CCE does not refer simply to disaffection or the lack of a family relationship, but rather requires the legitimary to engage in a very specific, serious behavior that can moreover be proven (Perez, 2014, Represa, 2016, González, 2015). I believe that the solution provided by the Supreme Court in its judgment of June 3,2014, is unsatisfactory. I am referring to the forced nature of its interpretation of the rule contained in the CCE. First, it makes it necessary to fit non-physical abuse within the legal concept of "mistreatment". It also requires considering neglect and lack of support and of a family relationship to be such abuse. The Supreme Court does identify this behavior with a series of actions "que determinan un menoscabo o lesión de la salud mental de la víctima". It appeals to the need for a flexible interpretation, in accordance with the social reality, cultural mores, and values of the times in which the events take place. However, in my view, not having a family relationship or neglecting elders can be a legal cause to disinherit, not only because it entails abuse of the testator, or not only when the latter supposes that it does, but rather because such neglect goes against the fulfillment of the family duties that should be preached not only with regard to parents vis-à-vis their descendents but also in the opposite direction, i.e., with regard to children vis-à-vis their parents. In addition, the lack of reciprocity shatters the coherence of the civil legal system itself, since, under the law, both childhood and old age are stages of life in which people need special protection. Hence, the foster care of minors in a legal situation of helplessness is regulated through the development of the Law on the Protection of Minors by 
each Spanish region, as is the care of the elderly, even within a family other than their natural one.

Therefore, the Supreme Court's new interpretation is not efficient for achieving friendlier intra-family relations. It is possible to neglect the duties of solidarity without mistreating the testator.

One consequence of this new case law is a wide range of decisions by the Provincial Courts. This has led to contradictions, with some courts aligning themselves with this new understanding of mistreatment, and others continuing to apply the Supreme Court's previous doctrine. The first group includes, for example, the Judgment of the Provincial Court of Malaga, December 26, 2014, JUR $2015 \backslash 194097$, which states that serious mistreatment or insults as justified causes of disinheritance must, by their nature, be subject to flexible interpretation according to the social reality, cultural sign, and values of the time in which they are taking place. The inclusion of psychological abuse is based on our own system of values, referenced, mainly, in human dignity as the seed or fundamental core of constitutional rights (Art. $10 \mathrm{CE}$ ) and its projection within the framework of family law as a channel of recognition of inheritance rights, especially the hereditary rights of the decedent's legitimary. He adds that the inclusion of psychological abuse, as a form of mistreatment, in keeping with the testator's expressed will has a clear projection within the framework of successions law in relation to the principle of "favor testamenti". Likewise, the Judgment of the Provincial Court of Santa Cruz de Tenerife of March 10, 2015 (AC 2015 \554), the Judgment of the Provincial Court of Castellón of February 12, 2015 (AC 2015\537), and the Judgment of the Provincial Court of Lugo of October 22, 2015 (JUR 2015\257457) establish that: “Tras las sentencias del T.S. de 3 de Junio de 2014 y 30 Enero de 2015 se abre la vía a una interpretación extensiva del concepto de maltrato que abarca no solo el de obra sino el psicológico. En efecto, las causas de desheredación son tasadas y no cabe su extensión pero sí puede efectuarse dentro de las existentes una interpretación extensiva de acuerdo con la realidad social (art. 3 del C. Civil) y de los principios de autonomía de la voluntad y de validez del negocio jurídico que en el caso podrían expresarse como favor testamenti. Así, si bien la ruptura emocional pasiva no es causa de desheredación, cuando se producen actos u omisiones que junto a tal ruptura provocan un sufrimiento o perturbación en el causante se estaría rebosando la tenue frontera entre la nula o mala relación y el maltrato psicológico suficiente para integrar la dicción legal'. The second group, i.e., that of restrictive interpretations of the causes of disinheritance, would include the Judgment of the Provincial Court of Barcelona of March 13, 2015 (SAP Barcelona, 13.03.2015, JUR 2015\121032): “Entendemos que la recurrente, en sustento de sus tesis en cuanto postula que se trata de un desheredamiento justificado, parte de una premisa que no podemos compartir, cual es que la causa de desheredamiento debe ser interpretada correctamente y en un sentido laxo al amparo de la voluntad de los testadores, quienes, según se alega, no desheredaron a sus nietas porque no les prestaran alimentos en sentido estricto, sino que el desheredamiento se fundaba 
en la falta de relación absoluta entre abuelos y nietas. Ello no es así. Los desheredamientos constituyen una institución que se manifiesta como una excepción al régimen de intangibilidad de la legítima, de modo que, insistimos, no cabe realizar interpretaciones extensivas, como la que propone el recurrente, sino que debe estimarse justificado únicamente cuando concurra una de las causas taxativamente dispuestas en la normativa aplicable. En suma, la desheredación ha de expresar de forma clara la causa legal en que se fundamenta y, en caso de ser negada, la prueba de los hechos corre a cargo del heredero."

Some judgments try to differentiate the circimstances included in the Supreme Court's new interpretation from those referred to in the Catalan case of disinheritance. Thus, for example, the Judgment of the Provincial Court of Cordoba of October 16, 2017(JUR\2017\300272), stresses that physical or emotional distancing or estrangement cannot be considered the type of psychological abuse that has been equated in the case law with mistreatment as a cause of disinheritance. Litigation over disinheritance due to mistreatment has increased, as has legal uncertainty. Urgent action by lawmakers seems necessary, even to amend the wording of Article 853.2 CCE in the sense indicated by the Supreme Court's new case law.

In connection with the "Catalan cause," Catalan lawmakers did take action on the matter in 2008, establishing in Article 451-17.2 e) CCCat that legitimaries can be disinherited due to"[1] aausenciamanifiesta y continuada de relación familiar entre el causante y el legitimario, siesporuna causa exclusivamente imputable al legitimario." The provision is intended to provide a rationale for the link between maintenance of the compulsory share and its evolution, in keeping with society's own, without ignoring developments in other legal systems (Barron 2017, I analyzed this legal provision in relation to comparative law, I referred to the American systems in force in Oregon and California, which, taking this approach to the extreme, consider it premature and, therefore, that any descendant who acts maliciously against the testator, exerts undue influence over him, or abuses his situation of old age or dependency loses all hereditary rights: Section 112.465 of the laws of the State of Oregon (Oregon Statutes), available at https://www.oregonlegislature.gov/bills_laws/lawsstatutes/2013ors112.html; and Section 259 of the California Probate Code, available at http://leginfo.legislature.ca.gov/faces/codes_displaySection.xhtml?lawCode=PR OB\&sectionNum $=259$. Thus, the legitimary system and the causes for disinheritance regulated in the current Catalan Civil Code offer a clear approach for systems that recognize inheritance rights based on behavior. For example, it is comparable with the provisions of Article 1621 A (8) of the Civil Code of Louisiana, which provides for a similar cause of disinheritance, allowing the parent to disinherit a child if the child, upon reaching adulthood, and providing he or she has the ability to maintain contact with his or her parent, has not done so without just cause for at least two years. The following article, 1622, allows grandparents to disinherit grandchildren under similar circumstances, regardless of whether the grandchild committed the offense against the parent or the grand- 
parent (Barrio, 2011; see the Louisiana Civil Code, available at

http://lcco.law.lsu.edu/?uid=60\&ver=en\#60.

This cause has existed since 1985 in a system - the only one in the United States that combines features of both civil and common law - that recognizes the legitimary rights of children, although the institution has gradually been eroded and weakened. One of the key mechanisms to achieve this is reversing the burden of proof, something that Catalan lawmakers have not done. In the Louisiana system, the cause indicated by the testator at the time of the disinheritance is presumed to be true, and it is the legitimary who must prove he or she has not spent two consecutive years without any relationship, that he or she did not know how to contact the testator, that he or she did not contact the testator for a just cause, or, simply, that he or she was forgiven by the testator or had reconciled with him (Art. 1624 Louisiana Civil Code: "The testator shall express in the instrument the reason, facts, or circumstances that constitute the cause for the disinherison; otherwise, the disinherison is null. The reason, facts, or circumstances expressed in the instrument shall be presumed to be true. The presumption may be rebutted by a preponderance of the evidence, but the unsupported testimony of the disinherited heir shall not be sufficient to overcome the presumption. [Acts 2001, No. 573, \$1, eff. June 22, 2001].” Art. 1625 Louisiana Civil Code: " $A$ person who is disinherited may overcome the disinherison by proving reconciliation with the testator after the occurrence of the reason, facts, or circumstances expressed in the instrument, provided he does so by clear and convincing evidence.") American case law has been dealing with the interpretation of this open cause of disinheritance for years, recognizing the lack of family relationship in cases in which the child is unable to prove that he or she has made any attempt to contact the parent in the aforementioned two-year period (Sonnekus, 2007).

The cause of disinheritance provided for under Article 451-17.2. e) CCCat is consistent with the current family model, based more on emotional ties than on strict ties of kinship. A separate issue is whether it can be claimed to be proving efficient at achieving lawmakers proposed objectives. Many authors warned of the risk of an increase in litigation (Lamarca, 2009; Ferrer, 2011; Arroyo \& Farnós, 2015) which is the reason for the rule's inefficiency (Ramos, 2007; Farnos 2014). An analysis of the cases that have dealt with this cause of disinheritance (Judgment of the Provincial Court of Tarragona, of March 10, 2016, JUR\2016198178; Judgment of the Provincial Court of Girona of December 28, 2017, AC\2017\1758; and Judgment of the Provincial Court of Barcelona, of April 25, 2017, JUR\2017\267047, among others) shows that judges are obliged to inquire about private family matters, with the heir bearing the burden of proof for many situations that are quite difficult to prove. Disinheritance lawsuits are becoming very similar to those dealing with the breakup of relationships, insofar as the trial delves into the moral or social level of family relations. Is this what the elderly testator, who will have died at the time of the disinherit- 
ance ordered in his or her will, wished?

There are several difficulties in the application of this cause. First, regarding the requirement of the imputability of the cause to the legitimary, the lack of a family relationship with the decedent must be due to a culpable attitude. However, family breakdowns often originate in the separation of the parents. Vaquer proposes dispensing with this factor (Vaquer, 2017). In my view, if the legitimary's responsibility is to be sought in the absence of a family relationship, then the judge cannot ignore the matrimonial crisis of the legitimary's parents and, above all, the events subsequent to it if they are responsible for the lack of family relationship being prosecuted. If the responsibility of the people entitled to a legitime for the lack of a family relationship is not entirely clear, the judge cannot consider the disinheritance established in the will to be just. Thus, for example, the Judgment of the Provincial Court of Girona of May 14, 2015, concerning a case in which the start of the lack of relationship began due to a family rupture resulting from the divorce of the disinherited party's parents, refuses to attribute the responsibility for the rupture to the legitimaries: "Aceptamos plenamente la argumentación jurídica que da el Juzgador respecto de esta causa de desheredación, especialmente en que la causa de desheredación sea imputable exclusivamente al legitimario, es claro que tal causa no está justificada, pues no puede imputarse a las nietas la falta de relación con su abuela, pues en el momento en que se otorgó el testamento tenían una seis años y diez meses y la otra cinco años, por lo que difícilmente puede imputárseles la falta de relación familiar a ellas, en su caso, tal falta de relación sería imputable al padre, que impide que su hijas se relacionen con la abuela, y dado que las causas de desheredación deben interpretarse restrictivamente ..." Judgment of the Provincial Court of Girona, 2nd, of May 14, 2015, AC 2015\1007. See also: Judgment of the Provincial Court of Barcelona, of March 31, 2016(ROJ: SAP B2475/2016). Additionally, this culpable lack of a relationship must have endured over time. (But for how long? Two years is not the same as ten years, and this imprecision facilitates arbitrariness. Lawmakers have not specified a minimum time for the lack of contact to qualify as continued, an issue that is regulated in Louisiana (Art. 1621), where the law stipulates a minimum term of two years.

Second, again, there is the issue of the burden of proof. The heir being sued by the people disinherited for this cause must prove a negative fact: a lack of family relationship that was moreover "manifest, the requirement of the lack of a manifest relationship does not require there to have been any previous coexistence between the parties affected by this lack of relationship (Farnós, 2014) i.e., that was significant enough to be known outside the strictly family sphere. The heir must also prove that it persisted at the time of the decedent's death.

This cause of disinheritance is clearly much more confusing than the others that allow the testator to deprive the legitimary of the compulsory share, which leaves a greater margin for the judge to decide in each case; thus, if there is insufficient proof, the cause will not prosper. In my view, to safeguard the freedom to deprive an heir of his or her compulsory share intended to be granted to the 
deceased, Catalan lawmakers would have done well to include the presumption of fact of the circumstances unless proven otherwise, i.e., they should have transferred the burden of proving that there was a family relationship with the deceased or that the legitimary was not at fault for the rupture to the legitimary.

\section{Conclusion}

As a conclusion of the whole paper, I pose two important questions that I will try to respond:

From a sociological perspective and in terms of efficiency, is old age, the best time in life to plan one's succession? In some ways, it is, because of the testator's life experience and deep knowledge of the family situation, at both the personal level and in terms of wealth and establishment. In other ways, it is not, because of the risks associated with longevity in relation to the exercise of testamentary freedom: the cases of inability to testate due to illness or old age increase, as do those of manipulation or intimidation of a vulnerable testator by the people closest to him or her, sometimes even relatives.

As for disinheritance, does it serve the greater cause, as it is currently regulated, of getting rid of unwanted legitimary descendants? Apart from the cases of serious criminally sanctioned behavior by the legitimary, in the vast majority of cases it does not. The case law shows that disinheritance does not increase the flexibility of the compulsory share. It does not increase the freedom of testation because, like the rest of the legislation concerning legitimaries, it serves the interests or raison d'être of that institution: the legitimary's right arises from bonds of blood, and it imposes on the testator a duty to convey part of his or her estate to his or her kin. Therefore, succession law does not reflect true reciprocity of the duties of care and support within the family. As a result, the unsupportive behavior of the legitimary is irrelevant in most cases from a prosecutorial point of view. In this sense, if disinheritance does not effectively sanction unsupportive behaviors, then nor can it encourage the opposite behavior, i.e., intra-family solidarity.

The solution to this problem is the introduction of new causes for disinheritance in the legitimary systems (something that has already been done in Catalonia and that, in a certain sense, also affects the other territories through the new doctrine in the case law on mistreatment). However, it also requires a reform of the institution of disinheritance, which is rigid and formal and subject to restrictive interpretation.

In short, rather than modifying or increasing the causes of deprivation of the compulsory share, if the aim is to afford true testamentary freedom to the testator, the compulsory share itself should be modified. The current legitimary system is overprotective of offspring and does not reflect the social, economic, and family reality of the times. To this end, I believe that more balanced solutions should be sought, such as a legitimary benefit of a credit-assistance nature for relatives of the deceased who can demonstrate a situation of need. This would allow the testator to freely dispose of the rest of the estate and with regard to 
those of his or her relatives who are not in need.

To completely eliminate the compulsory share would clash with the Western legal tradition and its understanding of family duties. However, to continue to nurture a sacred right to inheritance based on kinship is absolutely inappropriate in today's society. We must try to safeguard the family from possible errors or injustice in the testator's decision-making, but we must also safeguard the testator, as far as possible and especially once he or she has reached the age of 80 , from the painful task of punishing bad children with a mechanism that has moreover proven ineffective.

\section{Conflicts of Interest}

The author declares no conflicts of interest regarding the publication of this paper.

\section{References}

Albaladejo, M. (2013). Curso de Derecho civil V. Derecho de Sucesiones. Madrid: Tecnos. Albanese A. (2012). Il Codice Civile. Commentario (p. 39). Arts. 565-586, Milano.

Algaba, S. (2002). Efectos de la desheredación. Valencia: Tirant lo Blanch.

Algaba, S. (2011). Comentario al art. 852 CCE. In A. Cañizares, P. De Pablo, I. Orduña, \& E. Valpuesta (Eds.), Código civil comentado (p. 1014, Vol. 2). Pampplona: Aranzadi.

Algaba, S. (2015). Maltrato de obra y abandono emocional como causa de desheredación. InDret, 2.

Álvarez, H. (2014). El alcance de la desheredación: la desheredación parcial. In A. Domínguez, \& M. P. García (Eds.), Estudios de Derecho de Sucesiones, Liber Amicorum T.F. Torres García (p. 111). Madrid: Wolters Kluwer.

Arroyo, E., \& Farnós, E. (2015). Entre el testador abandonado y el legitimario desheredado? A quién prefieren los tribunales? InDret, 2, 4.

Barba, V. (2013). Il diritto delle successioni tra solidarietà e sussidiarietà in La revocazione delle disposizioni testamentarie e la modernità del pensiero di M. Allara. Natura della revoca, disciplina applicabile e criterio di incompatibilità oggetiva. Rassegnadi Diritto Civile, 3/2013, 739.

Barrio, A. (2011). La evolución de la libertad de testar en el common law inglés. Pamplona: Aranzadi.

Barrón, P. (2017). Límites a la libertad de testar en los derechos civiles españoles de legítima colectiva. In M. A. Parra, \& S. Gaspar Lera (Eds.), Derecho y Autonomía Privada: Una visión comparada e interdisciplinar (pp. 185-201). Granada: Comares.

Barrón, P. (2016). Libertad de testar y desheredación en los Derechos civiles españoles. InDret, 4, 11.

Barrón, P. (2016). Falta de trato familiar y desheredación de los descendientes. In C. Hornero, \& J. Ramos (Eds.), Derecho y fiscalidad de las sucesiones mortis causa en España: Una perspectiva multidisciplinar (pp. 93-110). Pamplona: Aranzadi.

Bartoli (2018). La tutela del patrimonio familiare. Affidamento fiduciario, atto di destinazione e trust. Milan.

Blasco, F. (2013). Instituciones de Derecho civil. Derecho de sucesiones. Valencia: Tirant lo Blanch. 
Bonilini, G. (2009). Trattato di Diritto delle Successioni e donazioni (Vol. 3). Milan.

Bonomi, A. (2011). Testamentary Freedom or Forced Heirship? Balancing Party Autonomy and the Protection of Family Members. In M. Anderson, \& E. Arroyo (Eds.), The Law of Succession: Testamentary Freedom (p. 27). Groningen: Europa Law Publishing.

Bosch, E. (2002). L'acreixement en el dret successori català. Barcelona: Departament de Jústicia, Generalitat de Catalunya.

Bosch, M. (2017). Cap a una millor posició successòria del cònjuge vidu o supervivent de la parella estable. Lo Canyeret, 96, 22.

Busto, J. (2015). Legítimas y reservas. In R. Bercovitz (Ed.), Manual de Derecho civil. Sucesiones (p. 207). Madrid: Aranzadi.

Campagnolo, R. (2011). Le successioni mortis causa. Milano.

Cantelmo, V. (1972). Fondamento e natura dei diritti del legittimario. Camerino.

Cañizares, A. (2014). Legítimas y libertad de testar. In A. Dominguez, \& M. P. García (Eds.), Estudios de Derecho de sucesiones. Liber amicorium Teodora F. Torres García (p. 249). Madrid: Walters Kluwer.

Carrau, J. M. (2015). La desheredación por maltrato psicológico y su dificultad de aplicación práctica. Revista de Derecho Civil, 2, 249-256.

Clemente, M. (2017). Desheredación por maltrato psicológico. In J. Alventosa, \& M. E. Cobas (Eds.), Derecho de Sucesiones (pp. 89-97). Valencia: Tirant lo Blanch.

De Almansa, A.(2012). Debe introducirse en el derecho civil común la falta de relación familiar como causa para desheredar a hijos y otros descendientes? Cuadernos Críticos del Derecho, Aletheia, 1, 30.

Del Pozo, P., Vaquer, A., \& Bosch, E. (2017). Derecho civil de Cataluña, Derecho de Sucesiones. Madrid: Barcelona-Buenos Aires, Bosch.

Delgado, J. (2012). Autonomía privada y derecho de sucesiones. In L. Prats (Ed.), Autonomía de la voluntad en el Derecho Privado: Estudios en conmemoración del 150 aniversario de la Ley del Notariado, Derecho de la Persona, Familia y Sucesiones (Vol. I, p. 540). Madrid: Wolters Kluwer.

Fernández, J. (2015). El apartamiento y el cálculo de la legítima en la Ley de Derecho civil vasco. In El Derecho Civil Vasco del siglo XXI, de la Ley de 2015 a sus Desarrollos Futuros (p. 429). Bilbao: Eusko Legebiltzarra/Parlamento Vasco.

Ferrer, J. (2011). La successió per causa de mort: Llibertat de disposar i interessos familiars. In C. Florensa, \& J. M. Fontanellas (Eds.), La codificación del Derecho civil de Catalunya (p. 345). Barcelona: Bosch.

Fusaro, A. (2011). Freedom of Testation in Italy. In M. Anderson, \& E. Arroyo (Eds.), The Law of Succession: Testamentary Freedom (p. 195). Groningen: Europa Law Publishing.

Galgano, F. (2012). Commentario compatto al Codice civile. Piacenza.

Galicia, G. (2016). La sucesión forzosa en el País Vasco. In M. C. Gete, \& J. Solé (Eds.), Tratado de Derecho de Sucesiones (p. 730, Vol. 2). Cizur Menor: Civitas.

García, C. (2014). La protección de la voluntad del testador vulnerable en Derecho inglés. In L. Diez-Picazo (Ed.), Estudios Jurídicos en Homenaje al Profesor José María Miquel (Vol. I, pp. 1499-1521). Madrid: Bosch.

García, M. P., \& Otero, M. (2016). Capacidad, incapacidad e indignidad para suceder. In J. Sole, \& M. C. Gete-Alonso y Calera (Eds.), Tratado de Derecho de Sucesiones (p. 260, Vol. I). Cizur Menor: Civitas.

Garrido, M. (2009). Derecho de sucesiones. Un estudio de los problemas sucesorios a 
través del Código civil y del Código de Sucesiones por causa de muerte en Cataluña. La planificación sucesoria (Vol. I). Madrid: Bosch.

Gil Rodríguez, J. (2016). Manual de derecho civil vasco. Barcelona: Atelier.

Gómez, F. (2009). Comentario al art. 412-3 CCCat. In J. Egea, \& J. Ferrer (Eds.), Comentari al Llibre quart del Codi Civil de Catalunya, relatiu a les successions (pp. 123-124). Barcelona: Atelier.

González, C. (2015). Desheredación por maltrato psicológico. Cuadernos Civitas de Jurisprudencia Civil, 277-288.

Hartog, H. (2012). Someday All This Will Be Yours. London: Harvard University Press. https://doi.org/10.4159/harvard.9780674062634

Jordano, I. (2004). Indignidad sucesoria y desheredación. Granada: Comares.

Jou, L. (2015). Institucions successòries a la pràctica notarial dels darrers anys. In L. Arnau, \& M. L. Zahíno (Eds.), Cuestiones de Derecho sucesorio catalán: Principios, legítima y pactos sucesorios (p. 132). Barcelona: Atelier.

Jou, L. (1994). Codi de Successions de Catalunya (Vol. II). Barcelona: Bosch.

Kerridge, J. (2000). Wills Made in Suspicious Circumstances: The Problem of the Vulnerable Testator. Cambridge Law Journal, 59, 310-319. https://doi.org/10.1017/S0008197300000143

Kerridge, J. (2002). Parry \& Clark (p. 69). London: The Law of Succession.

Lamarca, A. (2009). Relacions familiar i atribucions successòries legals. Llegítima i quarta vidual al Llibre IV del Codi Civil de Catalunya. In À. de D. Civil (Ed.), El nou dret successori del codi civil de Catalunya (p. 294). Girona: Universitat de Girona.

Lasarte, C. (2007). Abandono asistencial de la tercera edad y desheredación de los descendientes en la España contemporánea. In M. F. Moretón, \& P. López (Eds.), La protección de las personas mayores (pp. 363-380). Madrid: Tecnos.

López, A. (1997). La garantía institucional de la herencia. In Estudios de derecho público en homenaje a Juan José Ruiz (pp. 703-725). Madrid: Tecnos.

López, M. T., González, V., \& Sánchez, A. J. (2015). Personas mayores y solidaridad intergeneracional en la familia: El caso español. Madrid: Cinca.

Madoff, R. (1997). Unmasking Undue Influence. Minnesota Law Review, 216, 579-580.

Malaurie, C., \& Brenner, P. (2016). Droit des successions et des libéralités. París: L.G.D.J.

Mengoni, L. (2000). Successioni per causa di morte. In Trattato di Diritto civile e commerciale (p. 60, XLIII, 2). Milano: CEDAM.

Moscati, E. (2013). Patto di familia e tutela dei legittimari. In Studi Giuridici Europei (p. 261). Turin: G. Giappichelli Editore.

Navas, S. (2013). Child's Life, Step-Family and Decision-Making Process. European Overview. Beijing Law Review, 4, 63.

Orozco, C. (2016). La legítima: Voces a favor, voces en contra (pp. 26-29). Escritura Pública.

Parra, M. A. (2009). Legítimas, libertad de testar y transmisión de un patrimonio. Anuario da Facultade de Dereito da Universidade da Coruña, 13, 483.

Parra, M. A., \& Barrio, A. (2012). La legítima en Derecho aragonés. In T. Torres (Ed.), Tratado de legítimas (p. 362). Barcelona: Atelier.

Perez, M. (2014). Causas de desheredación y flexibilización de la legítima. In A. Domínguez, \& M. P. García (Eds.), Estudios de Derecho de Sucesiones, Liber Amicorum T.F. Torres (p. 1142). Madrid: Walters Kluvers. 
Perlingieri, G. (1951). La revocazione delle disposizioni testamentarie. Napoles: Edizioni Scientifiche italiani.

Perlingieri, P. (2005). Il diritto ereditario all'affacciarsi del nuovo millennio: Problemi e prospettive. In S. Delle Monache (Ed.), Tradizione e modernità nel diritto successorio. Dagli istituti classici al patto di famiglia (p. 317). Padua: CEDAM.

Ramos, R. (2007). Puede el juez contribuir a reducir la litigiosidad? Cuadernos de Derecho Judicial, 67, 13.

Rams, J., Moreno, R. M., \& Rubio, J. I. (2017). Apuntes de economía del matrimonio y derecho de sucesiones (p. 314). Madrid: Aranzadi.

Rebolledo, A. (2010a). Problemas prácticos de la desheredación de los descendientes por malos tratos, injurias y abandono de los mayores. In A. Rebolledo (Ed.), La familia en el derecho de sucesiones: cuestiones actuales y perspectivas de futuro (p. 381). Madrid: Dykinson.

Rebolledo, A. (2010b). La actualización del derecho sucesorio español ante los cambios sociológicos y jurídicos de la familia. Ibidem, 25-26.

Represa, P. (2016). La desheredación en el Código civil (p. 149). Madrid: Reus.

Ridge, P. (2004). Equitable Undue Influence and Wills. Law Quarterly Review, 120, 617-639.

Rivas, A. M. (2012). El ejercicio de la parentalidad en las familias reconstituidas. Portularia, 12, 30.

Rogel, C. (2017). El derecho a la herencia en la Constitución. Madrid: Reus.

Román, A. M. (2016). Derecho de Sucesiones. Madrid: Bosch.

Salas, F. (2014). Sobre la desheredación. Revista Aranzadi Doctrinal, 4, 3659.

Sánchez, M. P. (2016). Legítimas y protección constitucional de la herencia. Revista Jurídica del Notariado, 99, 367-412.

Sánchez-Rubio, A. (2012). La legítima. In J. Delgado, \& M. A. Parra (Eds.), Manual de Derecho civil aragonés (p. 628). Zaragoza: El Justicia de Aragón.

Sánchez-Rubio, A. (2016). La legítima en Aragón. In M. C. Gete, \& J. Solé (Eds.), Tratado de Derecho de Sucesiones (p. 532, Vol. 2). Cizur Menor: Civitas.

Scalise, R. J. (2008). Undue Influence and the Law of Wills: A Comparative Analysis. Duke Journal of Comparative International Law, 19, 41-106.

Sonnekus, J. C. (2007). Freedom of Testation and the Ageing Testator. In K. Reid, M. De Waal, \& R. Zimmermann (Eds.), Exploring the Law of Succession (p. 82). Edinburgh: The Edinburgh Law Review Trust and the Contributors.

Spivack, C. (2010). Why the Testamentary Doctrine of Undue Influence Should Be Abolished. Kansas Law Review, 58, 245-308.

Tatarano, M. C. (2008). La successione necessaria. In R. Calvo, \& L. Perlingieri (Ed.), Diritto delle successioni (p. 450). Napoles: Edizioni Scientifiche Italiane.

Torres, T., \& Dominguez, A. (2016). La legítima en el Código civil. In M. C. Gete, \& J. Sole (Eds.), Tratado de Derecho de Sucesiones (p. 398, Vol. 2). Cizur Menor: Civitas.

Torres, T., \& García, M. P. (2014). La libertad de testar: El principio de igualdad, la dignidad de la persona y el libre desarrollo de la personalidad. Madrid: Fundación Coloquio Jurídico Europeo.

Urrutia, A. (2016). La Ley 5/2015, de 25 de junio, de Derecho Civil Vasco. Comentarios breves, texto de la ley, antecedentes legislativos y formulario notarial. Bilbao: Dykinson.

Vallet, J. (1974). Limitaciones de derecho sucesorio a la facultad de disponer, tomo I, las 
Legítimas. Madrid: Instituto Nacional de Estudios Jurídicos.

Vaquer, A. (2015). La protección del testador vulnerable. Iuris Dictio, 14, 95-125. https://doi.org/10.18272/iu.v14i16.731 http://revistas.usfq.edu.ec/index.php/iurisdictio/article/view/731/1022

Vaquer, A. (2007). Reflexiones sobre una eventual reforma de la legítima. InDret, 3, 14.

Vaquer, A. (2017). Acerca del fundamento de la legítima. InDret, 4, 9.

Zubero, S. (2017). Ponderación de las limitaciones legales a la libertad de testar del causante. Revista de Derecho Civil, 4, 61. 